\title{
OBITUARY
}

\section{Dr. Malcolm A. Smith}

Dr. Malcolm Arthur Smith, a well-known authority on amphibians and reptiles, died at his home at Ascot on July 22 at the age of eighty-two.

He qualified M.R.C.S., L.R.C.P. in 1898 at Charing Cross Hospital and remained there for four years as house physician and surgeon before going to Siam, where he took up an appointment as medical officer to the British Legation in Bangkok. For almost a quarter of a century he practised medicine in Bangkok, during which period he acted as physician to the Court of Siam. He was one of the very few Europeans to come in contact with life at the Court and to have first-hand knowledge of its organization. On his return to Britain he wrote an interesting account of the remarkable happenings in the lives of the royal family which was entitled "A Physician at the Court of Siam", published in 1947.

His interest in herpetology gathered momentum as his zoological expeditions to the interior of Siam, Indo-China and Malay produced more rich and valuable collections, and he devoted more and more of his leisure time to the study of the Oriental species. He was an acute observer and a prolific writer, having more than a hundred publications to his credit. Most of these were based on classification and structure, although, more recently, he turned to considerations of evolutionary changes in the ear and the eyecovering of lizards, in snake dentition and in the head glands of snakes. His taxonomic studies reached a climax in an outstanding monograph on sea snakes and in the three volumes on the crocodiles and tortoises, the lizards, and the snakes, published in the "Fauna of British India" between 1931 and 1943 and after he had retired from Siam and had become an honorary associate of the British Museum. During the last decade or so of his life he committed himself to a study of the reptiles and amphibians of Great Britain, acknowledging with a wide comprehension the problems that were still unsolved or unpublished in that field. He became the author of yet another outstandingly successful book, "The British Amphibians and Reptiles", which was immediately recognized as a comprehensive and thoroughly reliable account of the structure, habits and behaviour of our British species. This is a book that is an invaluable guide to the specialist besides providing enjoyment to the layman, and it has become the standard work on the subject.

Not only an account of his scientific works shows him to have been an experienced and energetic personality, but the posts he held also indicate the zeal and devotion he gave to the advancement of herpetology. $\mathrm{He}$ was the first president of the British Herpetological Society from its inauguration in 1947 until 1954, recorder for the Amphibia and Reptilia section of the "Zoological Record" from 1929 until 1945 and editor from 1938 until 1949, and zoological secretary to the Linnean Society from 1939 until $1948 . \quad$ A. G. C. Grandison

\section{NEWS and VIEWS}

\section{Commonwealth Advisory Committee on Defence Science}

A meeting of the Commonwealth Advisory Committee on Defence Science is to be held in Australia during October 6-28. Sir Leslie Martin, defence scientific adviser to the Australian Department of Defence, will be the general chairman of the meeting. The Australian delegation will be led by Mr. W. A. S. Butement, chief scientist of the Department of Supply, and other delegations include Dr. J. E. Keyston, vice-chairman, Canadian Defence Research Board; Dr. D. S. Kothari, scientific adviser to the Indian Minister of Defence; Dr. Mohammed Afaf, Pakistan; Dr. S. M. Naude, seientific adviser, Department of Defence, South Africa; Sir Frederick Brundrett, scientific adviser to the United Kingdom Minister of Defence, Air Marshal Sir Geoffrey Tuttle, Deputy Chief of the Air Staff, and Dr. D. H. Black, director, Armament Research and Development Establishment. New Zealand will also be represented. These meetings are held at approximately three-yearly intervals and the last was in Canada in February 1956. The object of the Committee is to promote collaboration throughout the Commonwealth in the application of science to military affairs, and the meeting will be attended by senior defence scientists and senior officers of the armed forces of the Commonwealth.

\section{Imperial Cancer Research Fund}

Dr. J. Cratgie has resigned his post as director of the Mill Hill laboratories of the Imperial Cancer
Research Fund so that, free from administrative duties, he can devote himself entirely to research in the laboratories. His invaluable advice on problems of research will thus continue to be available to the Fund. Dr. R. J. C. Harris is joining the Fund's scientific staff on October 1 to take up a new appoint ment as head of the Division of Experimental Biology and Virology. He will also be responsible (under the director, Dr. G. F. Marrian) for the general administration of the Mill Hill laboratories. Mr. A. R. Currie, at present assistant pathologist at the Royal Infirmary, Glasgow, has been appointed head of the Division of Pathology, and will take up his duties on October 1, 1959. The Fund is meanwhile giving financial support to the cancer research he is undertaking in the Pathology Department of the University of Glasgow.

\section{Transfer of Controlled Thermonuclear Project from Harwell}

IT is proposed to remove the whole of the controlled thermonuclear project from the Atomic Energy Research Establishment, Harwell, to Winfrith Heath, Dorset. This change will permit the development of both fission and fusion work at Winfrith, and allow room for whatever expansion of the latter is necessary in the future. It will also provide a margin for new work as yet unseen which will undoubtedly be developed at Harwell. Winfrith Heath, which is near Dorchester, is a new site taken over by the United Kingdom Atomic Energy Author- 